\title{
Expression of language, culture and spirituality in world explanatory dictionary
}

\author{
Lolakhon Khamidovna Nigmatova ${ }^{1}$, Gudzina Viktoriya Anatolyevna ${ }^{2}$ \\ ${ }^{1,2}$ Bukhara State University, Uzbekistan \\ Email:xamidova1@umail.uz
}

\begin{abstract}
In article was written about literary meaning of language, culture and spirituality. Here was discussed about their dictionary meaning and meaning of these words in some writers works.

Keywords: language, culture, culture diffusion, spirituality, culture shock, lexicography.

\section{INTRODUCTION}

There is an issue that needs to be clarified at the beginning of the chapter: how do the terms of language, culture and culture coincide with the term spirituality? In other words, will these three terms in the classification of world languages be interpreted in the same way as in Uzbek? Or are they considered by many linguists to be part of the language?

No matter how amazing the questions are, in lexicographical terms of language, culture, and spirituality in the world lexicography it is not difficult to see the interrelationship between folk and professional languages. In particular, when lexemes of language, culture, and spirituality are considered as terminology, it should be checked in the global dictionary in special terminological dictionaries. Conversely, if the words studied are historically relevant to the dialectal layer of folklore, it is necessary to delineate definitions in the explanatory dictionaries of existing languages.
\end{abstract}

\section{LITERATURE REVIEW}

According to V.Mentrup, linguists began to consider the inclusion of professional vocabulary and argotisms in the compilation of the dictionary even in the seventeenth and eighteenth centuries [1, S. 4877.].

In addition to the linguistic and cultural-historical value of philosophies and arguments, Mr. Grimm wrote in his preface to the German Dictionary (1854) that "I learned all the words of history past with the importance of their traditions and language. " [1, S. 48-77.].

Naturally, the main issues raised in the lexicon of the 60-70s of the XX century were touched upon by the problems of anthropocentric paradigm such as language, culture, and spirituality. The main communicative situations and problems in those days were related to the interplay of professional language and folklore, and a number of linguists objected to this in some way to revise the principles of vocabulary. Here they are:

- Gipper (Gipper 1969). This scholar required linguistics to critically examine and improve professional languages;

- Weinrich (Weinrich 1976). He proposed a plan to create an interdisciplinary systematic dictionary that represents a single concept, taking into account the internal structure and interrelations of national and professional languages.

In general, since the second half of the twentieth century, lexicographical works have been placed on the basis of anthropocentric principles that are directly related to the trinity of language, culture and spirituality. Because, in the technocratic society, the linguistic content of the language was largely investigated on the principles of formal linguistics, whatever the system-structural direction, until the stimulation of cognitive sciences, assuming humanity and human factors. So far, West has seen Humboldt's belief that language testing with the spirit of the nation is appropriate only in the '80s and' 90s. Although, in Russian linguistics this development began in the late 60 's, 70 's and early 80 's, 
prominent Russian linguists E.M. Vereshchagin and V.G.Kostomarov proposed a Marxian-Leninist concept of language. These data refer to a century of world-old ideological wars that have begun to globalize. Artificial nutrients, from artificial fibers to artificial intelligence, and unlike civilization, a technocratic society that had followed the civilization, were not in a hurry to acknowledge the harmony of language and the spirit of the nation. In particular, the emergence of the term etalon in the literature, in some cases the criticism ofV. von Humbldt's theory of language and spirit [7, 224]., and Marr and I. Stalin's conceptions of a single language that excludes genealogical differences.

When planning for semantic information that should be recorded in dictionaries, J.P. Philmor gives valuable points, including: How to present lexical information when formalizing the language? ". In the context of these questions, the scientist makes critical remarks on the principle of "minimal interpretation" (Bendix's 1966) theory of lexical semantics [6, C.23-24].

\section{MAIN PART}

In particular, according to this principle, the semantic definition should only contain the signs that distinguish a particular lexical unit from another language. As a result of following this principle, a minimal, interconnected structural (lexical-semantic) network is formed, which corresponds to the ideal conclusions of linguists operating in the direction of structuralism. Consequently, when a lexical unit is omitted from the dictionary or when a new unit is inserted, the total lexical units that connect to that network are revised lexically and semantically. C.J.Fillmore sees the flaws of this approach in the following. That is, any word may, by its very nature, require a broad and detailed description. This is not in line with Bendix's "minimal definition" principle. Linguists (Birvish and Kiefer (Bierwisch-Kiefer) 1969), who aim to use the minimal interpretation principle to include all relevant semantic information in the dictionary, do one thing: they contradict the principle of language structure, separating the central and non-structural meaning of the word semantics. They act. A linguist who criticizes the principle of "minimal interpretation" also strongly condemns the inclusion of large-scale lexical-semantic links in the dictionary. Contrary to the minimal interpretation, according to this approach, all expressions that are within the semantic range of words should be enclosed in a dictionary. "Whereas such semantic intersecting links form an understanding chain between lexemes. According to him, the student first commented on one lexeme, followed by the second lexeme and the next. the lexeme will have to read the scope of the content." [2].

This aspect of the problem observed in world linguistics suggests that the harmonious interpretation of the language, culture, and culture words that we are investigating may pose specific complications in global linguistics. Consequently, in this chapter, we will look at this in more detail in the interpretation of folklore and national spirituality and culture.

V.P. Bolshakov promotes the following notions about culture and spirituality: In Russian ethics the terms "moral" and spirituality are comparative, but are understood as interrelated concepts. Therefore, it is necessary to take both of them in place of a similar term that is explained by human activities. In other words, spirituality represents the value orientation of human behavior based on the dichotomy of good and evil. Evil is not a value; goodness, on the contrary, is the basis of spiritual value. Goodness is not abstract, it is an attitude that is reflected in the thoughts, feelings, goals and actions of a person.[2].

Goodness is the key to spiritual values. Accordingly, goodness is the norm of behavior and attitude. This norm is internal, as an ideal of behavioral and spiritual relations. Thus, the ideal abstract characteristic differs from that of the individual.

Each civilization, in its evolution, forms some spiritual value that reflects the norms and forms of human relations.

"Culture" comes from the Latin word "cult", which means processing, processing, education, improvement, education, education [12].. Society as its constituent unit (nations, classes, social strata, professional associations) is considered as the subject of culture.[17].

MA Suhomlinova on the study of the terms "CULTURE" / "КУЛЬТУРА" emphasizes their etymology in antiquity and notes that no other word has such meaning. [5].

According to Gurevich, culture reflects the essence, boundaries of human life. The culture here is as multifaceted, multifaceted and inexhaustible as the human being. 
In ancient Roman manuscripts and treatises, "cult" (derived from the Latin "cult" root; Uzbek culture (from the "Madinah")) is literally compared to the culture of consciousness, spirit culture, the cult of gods, the cult of ancestors. The term has been in use for hundreds of years before the broad term civilization (Latin civilization) came to Latin, reflecting the combination of social heritage in the field of technology, science, art, and political organizations. a'lumotga own interpretation of the meaning of knowledge.

In the Middle Ages the word "cult" began to be used more frequently than cult. This expression expresses a man's ability to express his love for his Creator.

During the Renaissance, cultural diversity served to symbolize the creativity of the human being that promotes progress.

According to P.Gurevich, the word cultura began to be used in the modern sense in the 17th century. As an independent term, the German lawyer and historian S. Pufendorf began to be used in the research.[5].

According to A.V. Semyonov, the author of the Russian etymological dictionary, Russian культура was introduced in the eighteenth century in the sense of "plant reproduction." This word was fully understood in the nineteenth century. No scientist has yet explained the reasons for his entry into Russian. Usually, such factors include interaction with French (culture), German (Kultur) and English (culture) languages.

The English word "culture" has several meanings. The Online Etymology Dictionary says that the word cultural came into being in 1868 and refers to the care of plants and animals. From 1875 this word began to represent mental activity and later civilization. Soon sociologists and anthropologists began to use the term as part of an identifying device. In 1912, the term cultural diffusion (cultural diffusion) or diffusion cultured(cultural diffusion) emerged; ultra diversity in 1935; cultural imperialism from 1937; cultural pluralism from 1932; culture; cultural shock since 1947; culture shock expressions have become increasingly popular since 1940. Cultural + - ly (culturally) terms have been introduced since 1889, and cultural + - ization (culturalization) in 1929.

The conceptual scope of the term culture is varied in different dictionaries. More than 400 definitions of culturology vary from philosophical-anthropological, philosophical-historical, sociological approaches to existing concepts. Consequently, a number of explanatory dictionaries in Russian (SI Ojegov, N.Y. Shvedova. Tolkovy Slavic Russian Language - M., 1999; Philosophical Encyclopaedia. Under the term culturists, people who understand:

1) Achievements of people in production, spiritual sphere;

2) culture itself;

3) reproduction, reproduction of plants or animals;

4) reproduction of plant, microorganism cells in the production or laboratory nutritional conditions;

5) high level of something, high development, ability.

When analyzing a number of modern English dictionaries (Collins COBUILD English Language Dictionary - London; Glasgow: Collins; Stuttgart: Klett, 1987; The All Nations English Dictionary Edmonds: All Nations Literature, 1992; Oxford Advanced Learner's Dictionary. University Press, 2005, etc.) that the British understood "culture" as follows:

1) theideas, customs, beliefs and art that are produced or shared by a particular society;

2) a particular society or civilization, especially one considered in relation to its ideas, its art, or its way of life;

3) the intellectual and artistic aspects of a society;

4) the arts considered as a group, for example art, music, and literature, together with activity or interest in them;

5) the quality of being well-mannered and well-educated, especially when you have a good knowledge of the arts and an interest in them;

6) physical culture, beauty culture, etc is the development of your body or the improvement of your physical appearance;

7) the culture of bees, silkworms, fish, etc. is the practice of keeping, rearing, and breeding them for the substance that they produce; 
8) a group of cells or bacteria, especially one taken from a person or an animal and grown for medical or scientific study, or to produce food; the process of obtaining and growing these cells. [5].

\section{DISCUSSIONS}

Apparently, the semantics of the words "cultur" and "culture" differ. In other words, culture is used in English in the sense of "physical culture." Also, English and Americans, unlike Russians, emphasize personal health and physical fitness.[5].

No matter how different such classifications may be, the phenomenon of the division of culture into material and spiritual causes the emergence of these differences. However, it is necessary to acknowledge the coherence of spirituality in the world lexicon, particularly in Russian lexicography.

For example,

Ojegov's Explanatory Dictionary: The Possibility of the Priority of the Spiritual, Moral, and Intellectual Interests of the Sustainer

In the Dictionary of Synonyms: dukovnost: Faithfulness, Spirituality, Intellectualness, Sergeant (?).

"Chinese Philosophy. In the Encyclopedic Dictionary: dovovnost is a virtue.[3].

In the Russian Dictionary of idiomatics: dukovnost - high spirituality.[10].

In the "Little Academic Dictionary": The spiritual, intellectual nature of the individual against the physical and physical characteristics of the person.[4].

In the Russian Spelling Dictionary: duhovnost, duh l' ovnost, - i.[8]

In Kuznetsov's Explanatory Dictionary: The Possibility of the Priority of the Spiritual, Moral, and Intellectual interests over the Material Benefits. High spirituality. Loss of spirituality. Awakening of the spirituality of society. High spirituality determines the health of the nation.

In the ethnopsychological dictionary: a term used in the humanities of knowledge. D. - Opening of new forms of public life, responding to changing living conditions, a key factor in the development of civilization; the priority of a person's intellectual, spiritual, moral interests (values) over material students. It is formed on the basis of material and spiritual culture.[11].

Spiritual Encyclopedia describes spirituality as two fundamental needs of the individual: the ideal need for knowledge and the functioning of the interests of others, and the manifestation of the system of social needs.

The Dictionary of antonyms reverses the Dormovnost (Morality)

The ideological dictionary of the Russian language reflects the following comments.[9].

Spirituality

spiritual

A Personality orientation

Spirituality - priority of the intangible interests of the person over material interests;

high intangible value system (suffering \#);

oduhotvorennost(spiritual), oduhotvorit (divination).

oduxotvorennyy (divine).

spiritual world, duhovnyy (interests).

dushevny (spiritual). Vnutrenny (internal).

nravstvenny (moral) ( satisfaction).

Prometheus fire.

The Light of the Creator.[12].

In the Russian Encyclopedia, the word духовность(dukhovnost(spirituality))" is interpreted as the work of the soul, the atonement of sin, and the cleansing of the heart. "Dukhovnost (spirituality)" is shaped in the Russian world by the Orthodox, the hierarchy, the creation of icons, the church singing traditions, and the views of the local saints. In other words, the dhovnost is characterized by the primitive and natural geography of the Russian nation's psychology.[13].

In Efremova's Explanatory Dictionary, the eunuch is the intellectual, spiritual nature of the human being, contrary to the human substance, the intangible being, the high spirit, the aspiration for perfection.[13].

In the "Legal Dictionary," dhovnost is regarded as a system of high intangible values.[14]. 
In A.A.Zaliznyak's "Polnaya aktsentuirovannaya paradigm" book there are the following types of spirituality:духовность, духо́вность, духо́вности, духо́вности, духо́вностей, духо́вности, духо́вностям, духо́вность, духо́вности, духо́вностью, духо́вностями, духо́вности, духо́вностях (duxovnost, duxovnost, duxovnosti, duxovnosti, duxovnostey, duxovnosti, duxovnostyam, duxovnost, duxovnosti, duxovnostyu, duxovnostyami, duxovnosti, duxovnostyax(spirituality. In this paradigm, the dhokhnvnostey language, which does not conform to the laws of the Uzbek language, should be adopted in the form of spirituality. So it comes in different vocabularies, in contrast to the words in the languages of different language families.

\section{CONCLUSION}

In the explanatory dictionary of Ushakov, the word "dukhovnost" is defined as the refusal of material pleasures, sensual pleasures, inner perfection, and the aspiration for spirituality.[15].

As we have seen, spirituality(культура, culture) began to be interpreted in new interpretations from the beginning of the XXth century on the global stage, when human factors were examined in place of philosophical issues in science. This, in turn, has led to an increasing body of evidence that culture is expressed in the spirit of the nation and through it.

\section{REFERENCES}

1. Wolfgang Mentrup. Überlegungen zur lezikographischen Erfassung der Gemeinsprache und der Fachsprachen. - In: «Interdisziplinäres deutsches Wörterbuch in der Diskussion», Düsseldorf, 1978. - S. 48-77.

2. Bolshakov V. P. Culture as a form of humanity. Tutorial.

3. Chinese philosophy. Encyclopedic Dictionary. - M., 2009. http // endic.ru/china/Duxovnost-517. Html

4. Small academic dictionary. - M .: Institute of the Russian Language of the Academy of Sciences of the USSR A. Evgeniev P. 1957-1984. http // endic.ru/ademic/Duxovnost-7050. html

5. I International Scientific and Practical Internet Conference "Dialogue of Cultures - Dialogue on Peace and for Peace" (October 24-25, 2012)

6. New in foreign linguistics. - M .: Progress, 1983. - S. 23-24. (- 400 p.) 76. New in foreign linguistics. - M .: Progress, 1983. - S. 31-32. (- 400 p.)

7. Christmas Yu.V. Introduction to general philology. - M.: Higher School, 1979. - 224 p.

8. Russian Spelling Dictionary / Russian Academy of Sciences. Inst. Rus. lang them. V.V. Vinogradova. V.V. Lopatin (editor-in-chief), B.Z. Buchchina, N.A. Eskova, etc. - M .: Azbukovnik, 1999.

9. Dictionary of Antonyms, 2011. http // endic.ru/antonyms/Duxovnost-741. html

10. Dictionary of Russian idioms. Word combinations with a high degree value. - M.: Academic, 2011.

11. Ethnopsychological dictionary. - M .: MPSI. V.G. Krysko. 1999.

12. http// endic.ru//ruc_ideografic/Duxovnost-3879. html

13. http// endic.ru/efremova/legal/Duxovnost-22881. html

14. http// endic.ru/legal/Duxovnost-5395. html

15. http://endic.ru/ozhegov/Duhovnost-7911.html

16. https://www.gumer.info/bibliotek_Buks/Culture/Bolsch/03.php

17. https://students-library.com/library/read/43698-nravstvennaa-kultura-ponatia-istoriceskie-tockizrenia-na-proishozdenie-nravstvennosti-osnovnye-kategorii 